\title{
HTA on neonatal screening for rare metabolic disorders faced misconceptions and blurred objectivity
}

Ilona Autti-Rämö

From 6th European Conference on Rare Diseases and Orphan Products

Brussels, Belgium. 23-25 May 2012

\section{Background}

The genetic background of the Finnish population has led to a unique epidemiology for some the rare hereditary disorders. In particular the incidence of PKU-is very low, less than 1:100000. Finland has screened only for congenital hypothyroidism from cord blood since 1984. A proposal to start a pilot study on screening with MS/MS with the cost estimation of 1-3€/newborn necessitated a Health technology assessment (HTA). In this article the major problems encountered during the assessment process and thereafter are presented.

\section{Material and methods}

The original HTA project started form identifying the possible disorders to be screened for Finland, evaluating the possible costs of building up the screening organization, cost-effectiveness, organizational and ethical consequences $[1,2]$. The original documents from the HTA project and from the national screening committee at the ministry of social affairs and health were used.

\section{Results}

Lacking reliable data on incidence, natural course of the possible disorders, sensitivity and specificity of the screening tests, effect of early diagnosis and early treatment raised many ethical questions. It became evident that a thorough ethical evaluation was needed to answer questions like "Can infants become the focus of research to answer the unknown? When is it acceptable to screen for many to find a few?". Modeling a screening organization does not guarantee that it will work in real life but the estimated costs were $45 € /$ newborn for finding 5-10 children

Correspondence: ilona.autti-ramo@kela.fi

The Social Institution, Research Department, Finland with a rare metabolic disorder per year in Finland. The annual birth rate in Finland is approximately 56000.The national screening organization has discussed the topic at 17 meetings during 2003-2012, the chairpersons and committee members have changed. Seminars and workshops with content experts have been organized to answer the identified critical questions, yet more information was needed. A national pilot study was withdrawn; a local feasibility study was conducted. An HTA report on PKU screening when neither parent is of Finnish origin was conducted in 2008 [3].

\section{Conclusions}

The original assumptions on costs were fictional. A continuous conversation with the screening committee and the content experts has been necessary and understanding the complexity and consequences of the decision increased during the years. The ongoing changes in structuring health and social care and the planned changes in legislation affect how national screening programs can be implemented. Screening for metabolic disorders in newborn has so far not yet been expanded.

Published: 22 November 2012

\section{References}

1. Autti-Rämö I, Laajalahti L, Koskinen $H$, Sintonen $H$, Mäkelä M: Screening for rare metabolic dises in newborn infants. Finohta report 22/2204

2. Autti-Rämö I, Mäkelä $M$, Sintonen $H$, Koskinen $H$, Laajalahti $L$, Halila R, Kääriäinen H, Lapatto R, Näntö-Salonen K, Pulkki K, Renlund K, Salo M, Tyni T: Expanding screening for rare metabolic diseases in the newborn: An analysis of costs, effect and ethical consequences for decision making in Finland. Acta Paediatr 2005, 94:1126-1136.

3. Leipälä J, Saalasti-Koskinen U, Blom M, Autti-Rämö I, Gissler M, Hämäläinen E, Paganus A, isojärvi J, Kääriäinen H, Renlund M, Mäkelä M: Fenylketonurian seulonta Suomessa (Screening for phenylketonuria in Finland). Finohta; 2008. 
doi:10.1186/1750-1172-7-S2-A17

Cite this article as: Autti-Rämö: HTA on neonatal screening for rare metabolic disorders faced misconceptions and blurred objectivity. Orphanet Journal of Rare Diseases 2012 7(Suppl 2):A17.

Submit your next manuscript to BioMed Central and take full advantage of:

- Convenient online submission

- Thorough peer review

- No space constraints or color figure charges

- Immediate publication on acceptance

- Inclusion in PubMed, CAS, Scopus and Google Scholar

- Research which is freely available for redistribution

Submit your manuscript at www.biomedcentral.com/submit 